\title{
Does Gender Division of Labour Matters for the Differences in Access to Agricultural Extension Services? A Case Study in North West Ethiopia
}

\author{
Asres Elias ${ }^{1}$, Makoto Nohmi ${ }^{2}$, Kumi Yasunobu $^{2} \&$ Akira Ishida $^{3}$ \\ ${ }^{1}$ The United Graduate School of Agricultural Sciences, Tottori University, Japan \\ ${ }^{2}$ Faculty of Agriculture, Tottori University, Japan \\ ${ }^{3}$ Graduate School of Agricultural Science, Kobe University, Japan \\ Correspondence: Asres Elias, The United Graduate School of Agricultural Sciences, Tottori University, Japan. Tel: \\ 81-804-550-5224. Fax: 81-857-315-683.E-mail: asres97@yahoo.com
}

Received: September 2, 2014 Accepted: November 17, $2014 \quad$ Online Published: December 15, 2014

doi:10.5539/jas.v7n1p138 URL: http://dx.doi.org/10.5539/jas.v7n1p138

\begin{abstract}
Women farmers comprise, on average, $43 \%$ of the agricultural labour force in developing countries. However, despite their role in agricultural production, their work remains largely unrecognized and they have been virtually ignored by agricultural intervention programs. Thus the aim of this study is to analyze the gender division of labour in agricultural production and identify the real causes of women farmers' absence in agricultural extension services using a case study conducted in three rural villages of North West Ethiopia. Despite women's significant role in crop and livestock production in the study area, only $15.8 \%$ of women heads are users of the extension service whereas men heads account for the lion share (70.7\%). The quota system imposed on extension workers that led them to target resource-rich farmers combined with women's poor access to resources are the most important factors for the denial of women's client-ship in extension services. Capturing the differences between men and women in terms of productive assets should be boldly underlined to design gender responsive services. Moreover, minimizing the effect of quantitative targeting of clients and developing policies and programs that strengthen women's physical access to resources remain important.
\end{abstract}

Keywords: gender role, agriculture, agricultural extension service, constraints, Ethiopia

\section{Introduction}

Empowering poor and vulnerable household groups in a fundamental manner, as opposed to providing them with transitory support, has been increasingly sought as a way of ensuring their effective participation in the development process (Barrett et al., 2006). A critical aspect of promoting gender equality is the empowerment of women. Gender equality is an essential component for sustainable economic growth and poverty reduction (FAO, 2010). As a result several literatures have alerted development practitioners to give emphasis for gender-specific constraints faced by poor female farmers (Quisumbing \& Pandolfelli, 2010; Kiptot \& Franzel, 2012; Ragasa et al., 2013).

In many parts of the world and especially in developing countries females are the main farmers or producers who are actively involved in agriculture (FAO, 2009; Rahman et al., 2007). According to FAO (2011), females comprise, on average, 43 percent of the agricultural labour force in developing countries, ranging from 20 percent in Latin America to 50 percent in Eastern Asia and Sub-Saharan Africa. The same report argues that reducing gender inequalities in access to productive resources and services could produce an increase in yields on female's farms of between 20 percent and 30 percent, which could raise agricultural output in developing countries by 2.5 percent to 4 percent. Realizing these gains requires male and female farmers to have access to information and assistance. But despite of female farmers' role in agricultural production, their roles remain largely unrecognized and they have been virtually ignored by agricultural intervention programs (World Bank, 2010). Failure to recognize the different roles of males and females is costly because it results in misguided projects and programs, forgone agricultural output and incomes, and food and nutrition insecurity (FAO, 2010).

Globally, rural females, especially those from poor households, face a particular burden. This fact is also 
common phenomenon in Ethiopia. Even though gender division of labour in rural Ethiopia varies in terms of farming systems, cultural settings, location and the different wealth categories (Abera et al., 2006), female farmers perform up to 75 percent of farm labour, representing 70 percent of household food production in Ethiopia (USAID, 2013), contribute more than their male counterparts in crop production and management in Ambo district (Ogato et al., 2009).

However, in spite of the many farming activities they perform (EEA/EEPRI, 2006; Kassa, 2008), they are not perceived as farmers and agricultural decision makers. Traditionally, the farming systems research and extension approach has obscured the complexity of female's position in regard to household labour requirements (Frank, 1999). Furthermore, the community consider farming as inappropriate activity and physically demanding for females. When females do participate in extension activities they may not be provided equal recognition for their responsibilities and skills. This is because farmers and farming activities continue to be perceived as "male" by planners and agricultural service deliverers, thereby ignoring the important and increasing role females play in agriculture. Moreover, technology packages delivered by extension services sometimes reinforce stereotypic divisions of labour (Manfre et al., 2013). For instance Ethiopia's Women's Development and Change extension package provides advice related to horticultural production, raising of poultry and small ruminants on the basis of the assumption that female do not farm but garden (World Bank, 2010; Cohen \& Lemma, 2011).

In contrast to the national policy and Ethiopian government advocacy that strongly promote gender equality in all aspects of life, the top-down approach, the perception that "females are not farmers" and the focus on getting model farmers to adopt fixed-technology packages (World Bank, 2010) and serious selection bias during placement of program participants (Elias et al., 2013), the agricultural extension program tends to neglect poor farmers in general and female farmers in particular (Ogato et al., 2009; Umeta, 2013). Although gender training and mainstreaming take place in some areas, women focused extension approaches are limited, and gender considerations are missing at all levels (Buchy \& Basaznew, 2005). Furthermore, the development and dissemination of agricultural innovations rarely take gender-specific characteristics and requirements into account (Action Aid and CARE, 2012).

The PASDEP (Plan for Accelerated and Sustained Development to End Poverty) annual progress report 2007/8 states that PASDEP aims to reach all female headed households and 30 percent of married females in agricultural extension programs. However, according to the Growth and Transformation Plan (GTP) document of the Ethiopian government, increasing extension service to female farmers in rural areas remains challenging.

As stated above many research studies had been designed to investigate rural females' involvement in agriculture but there is still inadequate database on 'what kind of farm activities females do' in different regions of Ethiopia especially for female headed households. To integrate females in any agricultural development project's design and implementation as well as to understand how interventions can be best be targeted, it is essential to have a complete knowledge of 'what females do' in a specific location and cultural setting. Because extension service demands are location specific, flexible and often quick decisions and actions. Therefore, the purpose of this study is to analyze the gender division of labour in agricultural production in Amhara region, Gozamin district and to understand the level of female headed households' participation in the current agricultural extension program known as Participatory Demonstration and Training Extension System (PADETES). The gender division of labour in this study refers the inter-household division of labour.

\section{Data and Empirical Methods}

\subsection{Data Collection}

The data used in this study were obtained from a household survey conducted in three selected kebeles of Gozamin district, East Gojam zone, North West Ethiopia in May and June 2012. A multi-stage sampling procedure was used to select the district, kebeles and farm households. In the first stage, Gozamin district was selected purposively for satisfying the following criteria; where mixed farming (crop and livestock) is widely practiced, where extension program have been implemented for relatively longer period of time, the availability of different agro-ecologies and its representativeness to the Ethiopian highlands. The Ethiopian highlands comprise nearly $45 \%$ of the total land area of 1.12 million square $\mathrm{km}$, and support over $85 \%$ of the country's 92 million population that are overwhelmingly rural. The three kebeles were randomly selected out of the total 25 kebeles found in the district. Stratified random sampling technique was employed to select a total of 300 farm household heads (225 male heads and 75 female heads). Sample farmers were identified from a list made available by the front-line extension workers, and then the information was confirmed by the farmers. The data were collected using structured and pre-tested questionnaire. Interviews and focus group discussions were used to compliment the data obtained through the field survey. 


\subsection{Empirical Methods}

The extent of gender role in agricultural activities were measured by using a three point continuum namely 'Always', 'Sometimes' and 'Not at all'. Descriptive statistics, t test and chi-square tests are used to understand the variation in gender division of labour in agriculture, female headed households' participation in agricultural extension program and their access to and use of resources. The rank orders of constraints that inhibit female headed households' access to extension service are identified through calculating score values of the constraints. The constraint list included nine items and among these, the constraints given by the respondents as first constraint has given nine points and the last constraint has one point. And then, by sum up all values, the score value of each constraint is identified and the constraint that got the highest score value is taken as the most important constraint.

\section{Results and Discussion}

\subsection{Demographic Characteristics by Gender of Household Head}

Using simple mean comparison tests (Table 1), female heads differ significantly from their male headed counterparts across a number of dimensions. Female heads are on average less educated than male heads. The gender disparity in schooling is not limited to the education of the head but is also true for the household at large. Female headed households also tend to be smaller, family size and labour force in terms of adult equivalent scale. Household size is proportional to the amount of labour resources the household controls in a rural area because many farm operations (especially oxen ploughing) require intensive labour. Hence, with respect to labour endowments female headed households are at a disadvantaged position.

Table 1. Mean difference test of demographic characteristics, access to human, physical, capital and social resources by gender of household head

\begin{tabular}{|c|c|c|c|c|c|}
\hline \multirow{2}{*}{ Resources } & \multicolumn{2}{|l|}{ Mean } & \multicolumn{2}{|c|}{ Std.dev } & \multirow{2}{*}{ P-value } \\
\hline & Male & Female & Male & Female & \\
\hline Age of head & 45.3 & 46.7 & 10.8 & 7.54 & NS \\
\hline Education of head $(1=$ literate $)$ & 0.51 & 0.18 & 0.50 & 0.39 & $* * *$ \\
\hline Number of educated family members & 3.89 & 2.11 & 1.76 & 0.97 & $* * *$ \\
\hline Family size & 5.97 & 4.09 & 1.81 & 1.41 & $* * *$ \\
\hline Active family labour in adult equivalent & 3.03 & 2.42 & 1.01 & 1.03 & $* * *$ \\
\hline Land size in hectar & 1.44 & 0.89 & 0.64 & 0.37 & $* * *$ \\
\hline Livestock ownership in TLU & 7.54 & 3.54 & 3.82 & 1.71 & $* * *$ \\
\hline Credit $(1=$ Yes $)$ & 0.15 & 0.01 & 0.27 & 0.11 & $* * *$ \\
\hline Training $(1=$ Yes $)$ & 0.80 & 0.32 & 0.40 & 0.46 & $* * *$ \\
\hline Leadership position $(1=$ Yes $)$ & 0.27 & 0.01 & 0.44 & 0.11 & $* * *$ \\
\hline Membership in cooperatives $(1=$ yes $)$ & 0.87 & 0.38 & 0.02 & 0.06 & $* * *$ \\
\hline
\end{tabular}

Source: Own survey, 2012.

Notes: ${ }^{* *}$ and NS represent statistical significance at 1 percent and non-significance respectively.

Female headed households are also worse off compared to their male counterparts in terms of land and asset ownership. Male headed households own 1.4 hectares of land, on average, compared to 0.89 hectares for female headed households. Male headed households also have an average of 7.5 TLUs, which is significantly different from female headed households' holdings of 3.5 TLUs. In terms of capital and social resources, male heads, on average, have better access to credit, higher leadership position and member ship in cooperatives than female heads. All these indicate the disadvantaged position of female headed households' in terms of human, physical, capital and social resources. 


\subsection{Gender Division of Labour in Crop and Livestock Production}

As shown in Table 2 about 92 percent of male heads and about 82 percent of female heads, except for oxen ploughing for females, are engaged in crop production and related management activities. In the study area like male farmers who involved in all aspects of agricultural activities, majority of the rural female heads do manual ploughing, planting, weeding, harvesting, threshing, production transport, production storage and marketing. This fact is also observed by Ogato (2009), World Bank (2010) and USAID (2013) that state females are intimately involved in all aspects of agricultural production process. Unlike other activities their involvement in fertilizer and pesticide application is low. Mainly these two activities are undertaken by their sons' or relatives and/or they are not using inputs at all.

Table 2. Gender role for crop production in the three rural villages (Kebele's) during the main agricultural season

\begin{tabular}{|c|c|c|c|c|c|c|}
\hline \multirow{4}{*}{ Activities } & \multicolumn{6}{|c|}{ Frequency of doing crop production activities } \\
\hline & \multicolumn{2}{|c|}{ Always } & \multicolumn{2}{|c|}{ Sometimes } & \multicolumn{2}{|c|}{ Not at all } \\
\hline & Male & Female & Male & Female & Male & Female \\
\hline & $\begin{array}{l}\text { Number } \\
\text { (percent) }\end{array}$ & $\begin{array}{l}\text { Number } \\
\text { (percent) }\end{array}$ & $\begin{array}{l}\text { Number } \\
\text { (percent) }\end{array}$ & $\begin{array}{l}\text { Number } \\
\text { (percent) }\end{array}$ & $\begin{array}{l}\text { Number } \\
\text { (percent) }\end{array}$ & $\begin{array}{l}\text { Number } \\
\text { (percent) }\end{array}$ \\
\hline Oxen ploughing & $222(98.7)$ & $0(0.0)$ & $3(1.33)$ & $0(0.0)$ & $0(0.0)$ & $75(100.0)$ \\
\hline Manual ploughing & $175(77.8)$ & $69(92.0)$ & $37(16.4)$ & $3(4.0)$ & $13(5.8)$ & $3(4.0)$ \\
\hline Planting & $223(99.1)$ & $75(100.0)$ & $0(0.0)$ & $0(0.0)$ & $2(0.9)$ & $0(0.0)$ \\
\hline Weeding & $222(98.7)$ & $74(98.7)$ & $0(0.0)$ & $0(0.0)$ & $3(1.3)$ & $1(1.3)$ \\
\hline Fertilizer application & $150(66.7)$ & $25(33.3)$ & $72(32.0)$ & $25(33.3)$ & $3(1.3)$ & $25(33.3)$ \\
\hline Pesticide application & $102(45.3)$ & $20(26.7)$ & $52(23.1)$ & $5(6.7)$ & $71(31.6)$ & $50(66.7)$ \\
\hline Harvesting & $223(99.1)$ & $74(98.7)$ & $1(0.44)$ & $0(0.0)$ & $1(0.4)$ & $1(1.3)$ \\
\hline Threshing & $222(98.7)$ & $67(89.3)$ & $1(0.44)$ & $5(6.7)$ & $2(0.89)$ & $3(4.0)$ \\
\hline Production transport by cart & $218(96.9)$ & $38(50.7)$ & $5(2.22)$ & $32(42.7)$ & $2(0.89)$ & $5(6.7)$ \\
\hline Manual production transport & $140(62.2)$ & $72(96.0)$ & $39(17.3)$ & $0(0.0)$ & $46(20.4)$ & $3(4.0)$ \\
\hline Production storage & $140(62.2)$ & $75(100.0)$ & $45(20.0)$ & $0(0.0)$ & $40(17.9)$ & $0(0.0)$ \\
\hline Production market & $195(86.7)$ & $75(100.0)$ & $0(0.0)$ & $0(0.0)$ & $30(13.3)$ & $0(0.0)$ \\
\hline Total & $186(82.7)$ & $55(73.9)$ & $21(9.4)$ & $5.8(7.7)$ & $17.8(7.9)$ & $13.8(18.4)$ \\
\hline
\end{tabular}

Source: Survey data, 2012.

Figures in parenthesis are percentages.

Regarding the gender division of labour in livestock production (Table 3), about 71 percent of female heads are engaged in livestock production and related management activities whereas male heads involvement is only 36 percent. Pen cleaning, dung processing, feeding, poultry production, forage preparation as well as milking and milk processing are among the main activities performed by females. Majority of males are mainly involved in pen construction, herding, livestock selling, feeding and forage preparation respectively. 
Table 3. Gender role for livestock production in the three rural villages (Kebele's)

\begin{tabular}{|c|c|c|c|c|c|c|}
\hline \multirow{4}{*}{ Activities } & \multicolumn{6}{|c|}{ Frequency of doing livestock production activities } \\
\hline & \multicolumn{2}{|c|}{ Always } & \multicolumn{2}{|c|}{ Sometimes } & \multicolumn{2}{|c|}{ Not at all } \\
\hline & Male & Female & Male & Female & Male & Female \\
\hline & $\begin{array}{l}\text { Number } \\
\text { (percent) }\end{array}$ & $\begin{array}{l}\text { Number } \\
\text { (percent) }\end{array}$ & $\begin{array}{l}\text { Number } \\
\text { (percent) }\end{array}$ & $\begin{array}{l}\text { Number } \\
\text { (percent) }\end{array}$ & $\begin{array}{l}\text { Number } \\
\text { (percent) }\end{array}$ & $\begin{array}{l}\text { Number } \\
\text { (percent) }\end{array}$ \\
\hline Livestock pen construction & $199(88.4)$ & $16(21.3)$ & $20(8.9)$ & $9(12.0)$ & $6(2.7)$ & $50(66.7)$ \\
\hline Livestock feeding & $120(53.3)$ & $64(85.3)$ & $15(6.7)$ & $3(4.0)$ & $90(40.0)$ & $8(10.7)$ \\
\hline Pen cleaning & $11(4.9)$ & $71(94.7)$ & $0(0.0)$ & $0(0.0)$ & $214(95.1)$ & $4(5.3)$ \\
\hline Dung processing & $5(2.2)$ & $71(94.7)$ & $0(0.0)$ & $0(0.0)$ & $220(97.8)$ & $4(5.3)$ \\
\hline Milking and milk processing & $23(10.2)$ & $44(58.7)$ & $12(5.3)$ & $19(25.3)$ & $190(84.4)$ & $12(16.0)$ \\
\hline Livestock selling & $131(58.2)$ & $55(73.3)$ & $0(0.0)$ & $5(6.7)$ & $94(41.8)$ & $15(20.0)$ \\
\hline Herding & $138(61.3)$ & $0(0.0)$ & $17(7.6)$ & $52(69.3)$ & $70(31.1)$ & $23(30.7)$ \\
\hline Forage preparation & $70(31.1)$ & $48(64.0)$ & $23(10.2)$ & $0(0.0)$ & $132(58.7)$ & $27(36.0)$ \\
\hline Poultry production & $12(5.3)$ & $49(65.3)$ & $0(0.0)$ & $20(26.7)$ & $213(94.7)$ & $6(8.0)$ \\
\hline Fattening & $18(8.0)$ & $5(6.7)$ & $0(0.0)$ & $0(0.0)$ & $207(92.0)$ & $70(93.3)$ \\
\hline Total & $72.7(32.3)$ & $42.3(56.4)$ & $8.7(3.9)$ & $10.8(14.4)$ & $143.6(63.8)$ & $21.9(29.2)$ \\
\hline
\end{tabular}

Source: Survey data, 2012.

Figures in parenthesis are percentages.

\subsection{Crop Types Grown by Male and Female Headed Households}

Males are often viewed as being responsible for producing cash crops, while females are viewed responsible for producing subsistence crops for home consumption (Doss, 2002; World Bank, 2010). As a result technology packages delivered by extension services sometimes reinforce stereotypic divisions of labour (Manfre et al., 2013). However, the data presented in this study (Figure 1) revealed that substantial number of female farmers grow almost similar types of crops dominantly grown in the area such as teff, maize, wheat, barley, vegetables etc with their male counterparts and there are no crops that are grown exclusively by either male or female farmers in the study area, implying that we cannot divide crops in to those grown by male and those grown by female at least in the study area, but there might be variation from place to place.

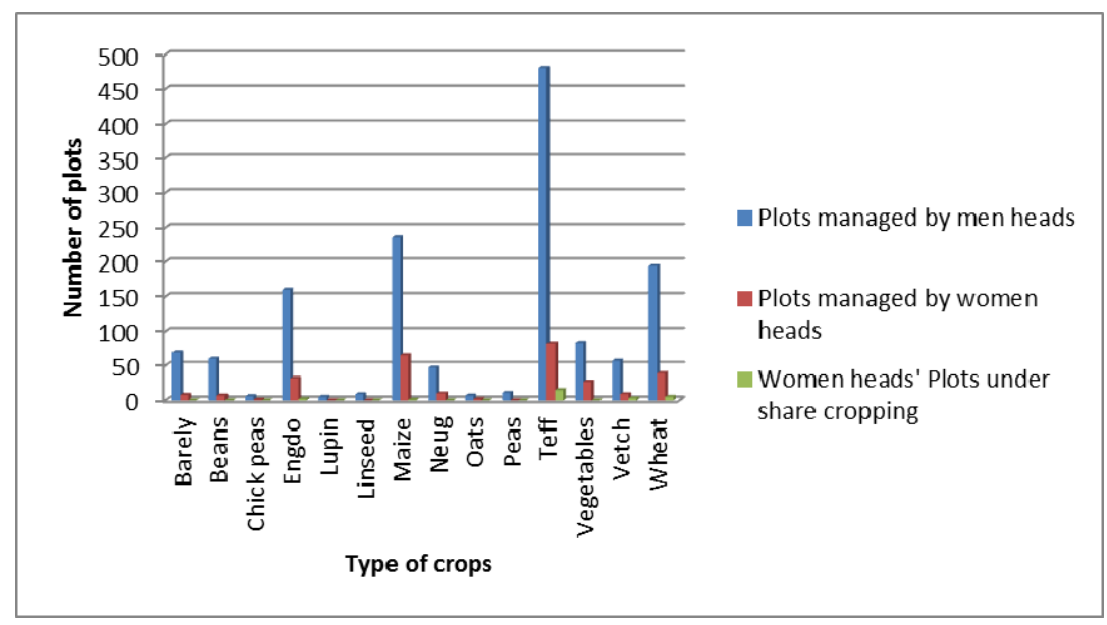

Figure 1. Crops grown by male and female headed households

Source: Own survey, 2012. 


\subsection{Gender-Labour Time Budget Analysis in Domestic and Farm Activities}

The time budget analysis (Table 4) indicates that females spent about 50 percent more time for domestic and farm activities compared to males. Gender differences become clearer when looking at female's workloads. Cooking and related activities (cleaning, child care, etc.), fire wood collection and fetching water are among the domestic activities they mainly perform. They also play significant role on farm work, poultry and livestock as well as vegetable gardening.

Table 4. Time budget analysis for gender division of labour (hrs/day) in the main agricultural season

\begin{tabular}{lll}
\hline Activities & Male heads & Female heads \\
\hline Cooking \& related works (cleaning, childcare...) & 0.005 & 5.893 \\
Fetching water & 0.020 & 0.885 \\
Fire wood collection & 0.247 & 0.952 \\
Vegetable gardening & 0.384 & 0.798 \\
Poultry and livestock related works & 0.398 & 0.870 \\
On farm work & 9.116 & 5.840 \\
Total & 10.17 & 15.24 \\
\hline
\end{tabular}

Source: Survey data, 2012.

\subsection{Gender Dimension in Agricultural Extension Services}

As stated above female farmers are actively engaged in agricultural production and management activities. However, irrespective of their role, the extension service remains dominated by males. Male heads are more likely receive advice from development or extension agents than female heads. As shown in Table 5, from the total farm households (2077 [298 female heads and 1779 male heads]) living in the three villages, only 15.8 percent of female headed farm households are users of the extension service whereas male headed farm households extension service users account for the lion share $(70.7$ percent). The result is consistent with other studies that observed access to extension services is lower for females as compared with males (Kassa, 2008; World Bank, 2010; Ragasa et al., 2013).

Table 5. Distribution of farmers according to their agricultural extension participation level in 2012

\begin{tabular}{|c|c|c|c|c|c|c|}
\hline \multirow{2}{*}{ Participation level } & \multicolumn{2}{|c|}{ Village 1 (Enerata) } & \multicolumn{2}{|c|}{ Village 2 (Wonka) } & \multicolumn{2}{|c|}{ Village 3 (Kebi) } \\
\hline & Male & Female & Male & Female & Male & Female \\
\hline Model farmers & 146 & 1 & 75 & 1 & 42 & 0 \\
\hline Copy (follower) farmers & 548 & 27 & 169 & 8 & 279 & 10 \\
\hline Traditional farmers & 229 & 64 & 252 & 157 & 39 & 30 \\
\hline Total & 923 & 92 & 496 & 166 & 360 & 40 \\
\hline
\end{tabular}

Source: Extension workers documented report, 2012.

\subsection{Constraints to Access Agricultural Extension Service for Female Headed Households}

In this section the first five most important constraints are discussed. During data pretesting one of the variable we used as a constraint was 'cultural (society) influence'. However most of the respondents clearly explained the influence is directly reflected by extension workers not by other members of the society. But it does not mean that there is no cultural influence at all as far as extension workers are part of the society rather we used the variable agricultural extension workers attitude because it is specifically related to our subject of study.

As shown in Table 6, agricultural extension workers attitude towards female farmers ranked as first constraint to access agricultural extension service. Farmers who participated in our focus group discussion explained that most of the time extension workers are not motivated to work with female farmers due to the low recognition towards female's agricultural responsibility, skill and their limited productive assets. More importantly based on 
our discussion with extension workers, they prefer to do with farmers who have better resource endowments that enable them to adopt the technology packages; just to skip the criteria used to evaluate the performance of extension workers i.e., the number of farmers adopting the technology packages in their mandate area. This fact is well observed by Kassa and Degnet (2004) that quotas (the minimum number of farmers who should take up the technology packages) are imposed on extension agents. As a result, extension agents use whatever means available to persuade farmers who are able to adopt the packages to take part in PADETES and thereby meet their quotas. In addition, Tewedaj et al. (2009) stated that the incentives of extension agents are set in a way that they try to maximize farmers' adoption of standardized packages. All these intensify quantitative targeting of clients and preference of resource full farmers by extension workers.

Table 6. Factors hindering female headed households' participation in agricultural extension service

\begin{tabular}{lll}
\hline Constraints & Score & Rank order \\
\hline Attitude of extension workers & 540 & $1^{\text {st }}$ \\
Shortage of family labour & 522 & $2^{\text {nd }}$ \\
Lack of credit access & 475 & $3^{\text {rd }}$ \\
Low education level & 396 & $4^{\text {th }}$ \\
High price of agricultural inputs & 335 & $5^{\text {th }}$ \\
Shortage of draft power & 276 & $6^{\text {th }}$ \\
Small land size & 200 & $7^{\text {th }}$ \\
Workload & 112 & $8^{\text {th }}$ \\
Lack of awareness & 63 & $9^{\text {th }}$ \\
\hline
\end{tabular}

Source: Survey data, 2012.

Even the strategy which has been designed to provide gender equitable extension service by recruiting female extension workers cannot handle the systematic discrimination of female farmers from extension services due to the quota system. Thus, the extension program needs to consider targeting mechanisms carefully because meeting quantitative targets may conflict with program objectives.

The second constraint faced by female headed households to access extension service is shortage of family labour. According to Bezabih and Holden (2007) female headed households are characterized by lack of assets (including draught power) as well as labour shortage in Ethiopia. More importantly, one of the characteristics of Ethiopian agriculture is its labour intensive nature which depends mainly on human labour and draft power. Previous studies observed that households who have large number of family size in adult equivalent scale have high likelihood of participation in the extension program (Elias et al, 2013; Botlhoko \& Oladele, 2013).

Lack of access to credit is another constraint to get extension service. Credit arrangements alleviate capital constraints of farmers that enable them to timely purchase of agricultural inputs promoted by the extension service. Credit users in the study area were only 16 percent, of which female heads have only 1 percent access that is influenced by the nature of credit arrangements that reduces the attractiveness of input uptake. To be eligible, a farmer must have repaid all previous loans (Dercon, 2000) and the capacity to pay the loan is evaluated. Inconvenient payback time and lack of interest due to the tendency of farmers to avoid risk in instances of crop failure (Carlesson et al., 2005) are other factors for farmers' low use of credit. Moreover according to Davis et al. (2010) in Ethiopia, farmers' access to agricultural credit (and financial services more broadly), remains inadequate, particularly female heads frequently lack credit, making it difficult for them to obtain inputs (Tewodaj et al., 2009).

Education is a major factor enabling females to break down barriers to some cultural and social factors giving rise to the division of household labour. However, female's low education level hampers their participation in the extension program. As shown in Table 1 only 18 percent of female heads are literate. According to Elias et al. (2013); Gebreegziabher et al. (2011); Giovanopoulou et al. (2011), education increases the probability of joining the extension program with the notion that farmers with better human capital like education are among the early adopters.

High price of agricultural inputs is another important barrier to use extension service for female heads who often 
lack productive assets and financial limitations. This is not surprising given the fact that most of the modern inputs (especially fertilizers and agro-chemicals) prices have been increasing year after year. The remaining constraints are lack of draft power, small land size, work load and lack of awareness respectively.

\section{Conclusions}

This study clearly indicates the involvement of female farmers in agricultural production and management activities. Female heads play a key role in both crop and livestock production and management activities in the study area. However, their important agricultural role is often obscured as a result of their non-contribution in oxen ploughing which is mainly done and culturally given to men. Though, their absence in oxen ploughing could not be a justification for perceiving them as non-farmers and/or seen to be only helping, but they are excluded from extension programs. Indeed female headed households' lack of productive assets also creates bias towards their agricultural role and in turn denies their access to agricultural extension service.

In general, the results of this study indicated the existence of male farmers dominated extension service. To reduce the gender gap in agricultural extension service, it is essential to promote female farmers' participation in agricultural extension activities by providing gender-responsive training to extension workers in particular and the community at large. Improving the criteria used for performance evaluation of agricultural extension workers and targeting mechanisms need attention to minimize the effect of quantitative targeting that may conflict with program objectives. Rather it is essential to make female's participation in training and skill development be part of the extension workers evaluation criteria until the gender gap becomes insignificant. In addition, capturing the differences between male and female farmers in terms of productive assets should be boldly underlined to design gender responsive services. Further, developing policies and programs that strengthen female's physical access to resources, and introducing time-saving infrastructures remain critical.

\section{References}

Abera, G., Gudeta, H., Belissa, M., Shale, G., Degefe, A., \& Kassa, B. (2006). Gender based roles and resource use right in potato production and marketing system: The case of some districts in Oromia, Ethiopia (A research report). Addis Ababa.

Action Aid and CARE. (2012). What works for women: Proven approaches for empowering women smallholders and achieving food security. Retrieved from http://www.actionaidusa.org/publications/

Barrett, C., Reardon, T., \& Webb, P. (2001). Nonfarm income diversification and household livelihood strategies in rural Africa: Concepts, dynamics, and policy implications. Food Policy, 26(4), 315-331. http://dx.doi.org/10.1016/S0306-9192(01)00014-8

Carlesson, F., Kohlin, G., Mekonnen, A., \& Yusuf, M. (2005). Are agricultural extension packages what Ethiopian farmers want? A stated preference analyses (Working paper No. 172). Department of Economics, Goteborg University.

Cohen, M. J., \& Lemma, M. (2011). Agricultural extension services and gender equality: An institutional analysis of four districts in Ethiopia (IFPRI Discussion Paper, 01094).

Davis, K., Swanson, B., Amudavi, D., Ayalew, D., Flohrs, A., Riese, J., ... Zerfu, E. (2010). In-depth assessment of the public agricultural extension system of Ethiopia and recommendations for improvement (IFPRI Discussion Paper, 01041).

Dercon, S. (2000). Growth and poverty in Ethiopia in the 1990s: An economic perspective. Centre for the study of African Economies, Oxford University.

Doss, C. R. (2002). Men's crops? Women's crops? The gender patterns of cropping in Ghana. World development, 30(11), 1987-2000. http://dx.doi.org/10.1016/S0305-750X(02)00109-2

EEA (Ethiopian Economic Association). (2006). Evaluation of the Ethiopian agricultural extension with particular emphasis on the Participatory Demonstration and Training Extension System (PADETES) (1st ed.). Addis Ababa, Ethiopia.

Elias, A., Nohmi, M., Yasunobu, K., \& Ishida, A. (2013). Effect of agricultural extension program on small holders' farm productivity: Evidence from three peasant associations in the highlands of Ethiopia. Journal of Agricultural Science, 5(8), 163-181. http://dx.doi.org/10.5539/jas.v5n8p163

FAO. (2009). Gender in Agriculture: Sourcebook. Retrieved from http://www.genderinag.org/content/gender-agriculture-sourcebook

FAO. (2010). Gender dimensions of agricultural and rural employment: Differentiated pathways out of poverty 
status, trends and gaps. Food and Agricultural Organization of the United Nations, the International Fund for Agricultural Development and the International Labour Office Rome.

FAO. (2011). The state of food and agriculture 2010-2011. Rome: Food and Agriculture Organization of the United Nations.

Frank, E. (1999). Gender, agricultural development and food security in Amhara, Ethiopia: The contested identity of women farmers in Ethiopia. USAID/Ethiopia.

Gebregziabher, K., Mathijs, E., Maertens, M., Deckers, J., \& Bauer, H. (2011). Extension participation, household income and income diversification: A system equations approach. Retrieved from http://www.csae.ox.ac.uk/conferences/2011-EDiA/.../437

Gebremedhin, B., Hoekstra D., \& Tegegne, A. (2006). Commercialization of Ethiopian agriculture: extension service from input supplier to knowledge broker and facilitator (Working Paper 1, 36). IPMS (Improving Productivity and Market Success) of Ethiopian Farmers Project.

Gebreselassie, S. (2006). Intensification of smallholder agriculture in Ethiopia. Options and scenarios paper presented for the Future Agricultures Consortium meeting at the Institute of Development Studies.

Giovanopoulou, E., Nastis, S. A., \& Papanagiotou, E. (2011). Modeling farmer participation in agri-environmental nitrate pollution reducing schemes. Ecological economics, 70, 2175-2180. http://dx.doi.org/10.1016/j.ecolecon.2011.06.022

Kassa, B. (2003). Agricultural extension in Ethiopia: The case of participatory demonstration and training extension system. Journal of Social Development in Africa, 181, 49-83.

Kassa, B., \& Abebaw, D. (2004). Challenges facing agricultural extension agents: A case study from South-Western Ethiopia. African Development Review, 16(1), 139-168. http://dx.doi.org/10.1111/j.1467-8268.2004.00087

Kassa, H. (2008). Agricultural extension in Ethiopia: Historical evolution, relevant policies and challenges. In Taye Assefa (Ed.), Digest of Ethiopia's national policies, strategies and programs. Addis Ababa: Eclipse Printers.

Kiptot, E., \& Franzel, S. (2012). Gender and agroforestry in Africa: a review of women's Participation. Agro-forestry System, 84, 35-58. http://dx.doi.org/10.1007/s10457-011-9419-y

Manfre, C., Deborah, R., Andrea, A., Gale, S., Kathleen, C., Mercy, A., \& MEAS Project. (2013). Reducing the gender gap in agricultural extension and advisory services: How to find the Best Fit for men and women farmers. MEAS discussion paper series on Good Practices and Best Fit approaches in extension and advisory service provision, USAID.

Ogato, G. S., Boon, E. K., \& Subramani, J. (2009). Improving access to productive resources and agricultural services through gender empowerment: A case study of three rural communities in Ambo district, Ethiopia. Journal of Human Ecology, 27(2), 85-100.

Quisumbing, A. R., \& Pandolfelli, L. (2010). Promising approaches to address the needs of poor female farmers: Resources, constraints, and interventions. World Development, 38(4), 581-592. http://dx.doi.org/10.1016/j.worlddev.2009.10.006

Ragasa, C., Guush, B., Fanaye, T., \& Alemayehu, S. T. (2013). Gender differences in access to extension services and agricultural productivity. Journal of Agricultural Education and Extension, 19(5), 437-468. http://dx.doi.org/10.1080/1389224X.2013.817343

Rahman, S. A., \& Ibrahim, H. (2007). Socio-economic study of gender role in farm production in Nasarawa State of Nigeria. Asia-Pasfic Journal of Rural Development, 1, 57-66.

Spielman, D. J., Kelemework, D., \& Alemu, D. (2011). Seed, fertilizer, and agricultural extension in Ethiopia. Ethiopia Strategy Support Program II (ESSP II) (Working Paper, 20, IFPRI).

Tewodaj, M., Cohen, M. J., Birner, R., Lemma, M., Randriamamonjy, J., Tadesse, F., \& Paulos, Z. (2009). Agricultural extension in Ethiopia through a gender and governance lens. IFPRI: Washington D.C.

The Federal Democratic Republic of Ethiopia. (2010). Growth and Transformation Plan (GTP) 2010/11-2014/15 Draft. Ministry of Finance and Economic Development (MoFED).

Umeta, G. (2013). Analysis of female headed households' participation in agricultural extension package program in East Showa Zone, Ethiopia. American Journal of Research Communication, 1(8), $227-245$. 
USAID. (2013). Empowering women through agricultural development in Ethiopia. http://www.usaid.gov

World Bank. (2010). Agriculture and rural development series: Gender and governance in rural Service: Insight from India, Ghana, and Ethiopia. World Bank, Washington, D.C.

\section{Copyrights}

Copyright for this article is retained by the author(s), with first publication rights granted to the journal.

This is an open-access article distributed under the terms and conditions of the Creative Commons Attribution license (http://creativecommons.org/licenses/by/3.0/). 